IRENA WODZIANOWSKA - LUBLIN

WITALIJ ROSOWSKI - LUBLIN

\title{
XIX MIĘDZYNARODOWA KONFERENCJA HISTORIA RELIGII NA UKRAINIE, LWÓW 13-15 MAJA 2009 ROKU
}

W połowie maja 2009 roku Lwów kolejny raz stał się miejscem międzynarodowej dyskusji naukowej poświęconej dziejom religii na ziemiach Ukrainy. Od dziewiętnastu lat Muzeum Historii Religii we Lwowie przy współpracy z Narodową Akademią Nauk Ukrainy jest organizatorem konferencji, która gromadzi religioznawców, filozofów, archeologów, historyków, historyków sztuki i muzealników z różnych regionów Europy Srodkowej i Wschodniej. Współorganizatorami tegorocznej konferencji byli: Instytut Religioznawstwa (filia Lwowskiego Muzeum Historii Religii), Lwowski Oddział Instytutu Ukraińskiej Archeografii i Źródłoznawstwa im. M. S. Hruszewskiego NAN Ukrainy, Oddział Religioznawstwa Instytutu Filozofii NAN Ukrainy im. G. Skoworody, Lwowski Regionalny Instytut Administracji Państwowej Narodowej Akademii Administracji Państwowej przy Prezydencie Ukrainy i Wydział do Spraw Narodowości i Religii Lwowskiej Obwodowej Administracji Państwowej. W obradach uczestniczyło ponad 300 przedstawicieli z różnych instytucji i ośrodków naukowych i muzealnych. Warto podkreślić, że do Lwowa przybyli naukowcy i muzealnicy nie tylko z prawie wszystkich regionów Ukrainy, reprezentujący 47 wyższych uczelni i 14 muzeów, a także gości zagraniczni z Białorusi (Brześć i Mińsk), Litwy (Szaulaj i Wilno), Polski (Lublin, Poznań, Toruń, Warszawa i Wrocław), Rosji (Moskwa), Słowacji (Preszów) i Węgier (Niredhaza).

Słowo powitalne do uczestników XIX Międzynarodowej Konferencji „Historia religii na Ukrainie" wygłosił Ksiądz Arcybiskup Mieczysław Mokrzycki, metropolita lwowski, a zarazem przewodniczący Konferencji Episkopatu Ukrainy obrządku łacińskiego. Mówca podkreślił, iż nieocenionym bogactwem tego państwa jest współistnienie obok siebie wielu religii i narodowości. Naocznym przykładem tego jest Lwów, gdzie zrodziła się idea organizowania najstarszej tego typu konferencji na Ukrainie. Następnie głos zabrali przedstawiciele komitetu organizacyjnego i władz regionalnych. Główne obrady toczyły się w murach Lwow- 
skiego Muzeum Historii Religii, mieszczącego się w gmachu podominikańskiego klasztoru. Ponadto prace niektórych paneli dyskusyjnych, na które została podzielona konferencja, odbywały się w pomieszczeniach Lwowskiego Muzeum Historycznego, Muzeum-cerkwi sztuki sakralnej im. A. Petruszewycza (budynek dawnego kościoła pw. św. Kazimierza przy klasztorze reformatów) oraz Lwowskiego Seminarium Duchownego i Akademii Ukraińskiej Prawosławnej Cerkwi Patriarchatu Kijowskiego, mieszczących się w dawnym klasztorze sióstr franciszkanek od wieczystej adoracji. Przy tak ogromnej liczbie uczestników i zróżnicowanych tematach, obrady konferencji zostały pogrupowane w kilku sekcjach. Nie sposób omówić wszystkich referatów, dlatego ograniczymy się w tym miejscu do przedstawienia w ogólnych zarysach problematyki podejmowanej w poszczególnych grupach. Pierwsze trzy skupiały się wokół dziejów religii i Kościołów chrześcijańskich na ziemiach ukraińskich od starożytności do czasów współczesnych. Tematy poruszane w pierwszej sekcji oscylowały wokół religijnego światopoglądu i wartości uznawanych przez dawnych Słowian oraz symboliki i pamiątek pogańskiej i wczesnochrześcijańskiej kultury. W następnej dyskutowano nad problemami historii chrześcijaństwa na Ukrainie od czasów średniowiecza do nowożytności. Ze względu na rozległość poruszonych tematów i liczbie zgłoszonych prelegentów (73 referaty) sekcja ta została podzielona na trzy części: katolicyzm i prawosławie w wieku XIV-XVIII, protestantyzm oraz kościoły chrześcijańskie pod rządami imperialnymi Rosji i Austro-Węgier. Sekcja trzecia, zamykająca część historyczna, dotyczyła trudnego okresu politycznych i duchownych zmagań mieszkańców ziem ukraińskich w najnowszym okresie ich dziejów, jak również sytuacji religijnej społeczeństwa w dniu dzisiejszym. W pozostałych trzech sekcjach omawiano problematykę rozwoju myśli religijnej i filozoficznej na Ukrainie, religie wschodnie i sprawy dotyczące sztuki sakralnej. W tej grupie w sposób szczególny naszą uwagę zwrócił ostatni panel, poświęcony architekturze, ikonografii, piśmiennictwu i różnego rodzaju zabytkom sakralnym i ich ochronie. Obrady i dyskusje wokół poszczególnych tematów były tym owocniejsze, że uczestnicy mieli już przed sobą wydrukowane materiały konferencyjne w dwóch obszernych tomach (tylko tom pierwszy zawiera ponad 1000 stron) naukowego rocznika „Historia Religii na Ukrainie”, wydanego przez wydawnictwo Lwowskiego Muzeum Historii Religii „Logos”.

Dodatkowo w ramach prac konferencji odbyły się trzy okragłe stoły, w których wzięli udział przedstawiciele świata nauki, mediów i władz państwowych. Pierwszy został poświęcony rocznicy 20-lecia wyjścia z ukrycia Ukraińskiej Greckokatolickiej Cerkwi. W drugim dyskusje skupiły się wokół bardzo obszernego i jakże aktualnego tematu „Religia - mass-media - społeczeństwo”. W ostatnim poruszono problemy ekologii w kontekście współpracy nauki i religii. Po owocnych dwudniowych obradach uczestników konferencji czekała sesja wyjazdowa. Jej program obejmował zwiedzanie zamku i bogatych zbiorów muzeum w Olesku oraz dawnego klasztoru i sanktuarium maryjnego ojców dominikanów w Podkamieniu, odnawianym obecnie przez zakon studytów. Wyjazd ten sprzyjał podjęciu nowych dyskusji i wymianie poglądów oraz stał się elementem integracyjnym międzynarodowego środowiska naukowego. 
Na koniec warto podkreślić, że z roku na rok liczba uczestników konferencji wzrasta, co też świadczy o potrzebie kontynuowania publicznej debaty na poruszane tematy. Niewątpliwie tego rodzaju spotkania na forum międzynarodowym stwarzają niepowtarzalne okazje do wspólnych rozmów, wzajemnego zrozumienia i znalezienia dróg rozwiązania trudności i problemów życia religijnego w realiach ukraińskich. 